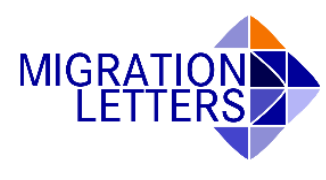

First Submitted: 10 April 2019 Accepted: 10 October 2019

DOI: https://doi.org/10.33182/ml.v17i1.753

\title{
Diasporas' Multiple Roles in Peace and Conflict: A Review of Current Debates
}

\author{
Mari Toivanen ${ }^{1}$ and Bahar Baser ${ }^{2}$
}

\begin{abstract}
Diasporas can play multiple roles in both the host country and the homeland, and their activities can varyingly contribute towards peace-building processes or perpetuate conflict back home. In this article, we wish to reflect upon the current discussions in this field, while considering the heterogeneity between and within diaspora communities as well as the generational dynamics of diaspora activism. We discuss intra-diaspora group relations as potential avenues of conflict and peace-building that transcend nation-states' borders. Moreover, we consider how the dynamics of peace-building and conflict perpetuation can transform over time with subsequent generations. We also discuss the role the second generation can play in relation to peace and conflict.
\end{abstract}

Keywords: diaspora; peace; conflict; second generation; transnationalism; diaspora-diaspora relations.

\section{Introduction}

According to the United Nations, around $3.5 \%$ of the world population currently live outside their countries of birth. In fact, the number of long-term international migrants is estimated at 272 million (United Nations, 2019). Whilst the reasons for migration vary greatly, a sizeable proportion of migrants leave their homelands behind due to the lack of human and environmental security, lack of social justice, fleeing violent conflict, violation of human rights and/or natural disasters. For instance, in 2015, a total of 60 million people were forcefully displaced due to wars, famine or natural disasters and around 20 million of them were displaced across international borders (Safer World, 2016). Growing in volume and intensity, migration has become one of the most important forces that is shaping today's politics in the world, not the least evidenced by the so-called refugee crisis in the Middle East and how it has restructured the political power relations in the region and beyond. Whilst global deaths in violent conflicts have continued to steadily decrease in recent decades (Roser, 2016), the on-going conflicts as well as peace-building initiatives are taking new shapes and forms, in part, due to the increased mobility and long-distance participation of diaspora communities in homeland affairs. Under these circumstances, it becomes vital to scrutinise the

\footnotetext{
${ }^{1}$ Mari Toivanen, PhD, Postdoctoral Researcher, Swedish School of Social Science, University of Helsinki, Finland, and affiliated member of the School for Advanced Studies in Social Sciences (EHESS) in Paris, France. E-mail: mari.toivanen@helsinki.fi.

${ }^{2}$ Bahar Baser, $\mathrm{PhD}$, Associate Professor, Centre for Trust, Peace and Social Relations, Coventry University, United Kingdom, and Research Fellow, Security Institute for Governance and Leadership in Africa (SIGLA), Stellenbosch University, South Africa. Email: bahar.baser@gmail.com.

Acknowledgements: We wish to thank the anonymous reviewers for their insightful comments. The research has received funding from the Academy of Finland as part of the project Transnationalism as a Social Resource among Diaspora Communities (project no 295417) and from the British Academy/ Newton Fund Mobility Grant (NMG2R2 $\backslash 100111)$. Dr Toivanen wishes to thank the Swedish School of Social Science (University of Helsinki) and the Sociology Department at the Catholic University of the Sacred Heart for their support.
} 


\section{Diasporas' Multiple Roles in Peace and Conflict: A Review of Current Debates}

impact of international mobility on peace and conflict in different societies, in particular, the role the diasporas can play in both the host country and the homeland.

Migration literature has long emphasised that migrants' arrival in the host country does not mean that their identity is reset to a "blank slate": ethnicity and religion, which are the touchstones of identity politics, continue to be meaningful to them. As their identities travel with them, it can be argued that the conflict dynamics back in the homeland, including intra-ethnic disputes, ethnonational conflicts, civil wars and even massacres, also travel with them. However, depending on the host country context, these dynamics can take new shapes and forms, thus restructuring intra-ethnic relations differently from the homeland context (Baser, 2015; Féron, 2017). Not limited to forced migrants, modern diaspora communities consist of students and labour migrants, who also foster a sustained interest and engagement towards their homeland, while at the same time integrating to the host country. This interest and engagement have been shown to extend also to diaspora communities' subsequent generations (Levitt 2009), thus raising questions about the role they can play in peace and conflict in their ancestral homeland.

In this article, we wish to reflect upon what role diaspora groups play in fostering peace and/or in perpetuating conflict in homeland. While doing so, we consider the heterogeneity between and within diaspora communities, including the generational dynamics. We also discuss diasporadiaspora relations to provide better understanding of the possibilities and challenges involved in diasporas' peace-building efforts in their homelands. In the following pages, we first examine the multiple roles diasporas play in peace and conflict, then discussing the triadic relationship between the diaspora, homeland and host country. We also consider it crucial to look beyond those relationships and discuss two understudied aspects that deserve more attention, if we are to understand better diasporas' multiple roles in peace and conflict. Firstly, we will discuss the diaspora-diaspora group relations as potential avenues of conflict, peace-building and conflict transformation. Secondly, we consider how the generational dynamics shape diasporas' engagement in peace-building efforts and conflict perpetuation in the long run.

\section{Diasporas as Peacemakers, Peace-Breakers or Something In-Between?}

Diaspora engagement in peace and conflict in the home and host countries has become a serious matter for debate in academia as well as among policy-makers in recent years. One of the reasons for this was 9/11 and its aftermath, which set the stage for several countries declaring the War on Terror. It also opened the Pandora's box of "homegrown terrorism", with migrants considered to represent a potential security threat in their countries of residence and therefore, becoming an object of securitisation practices (Faist, 2002; Cochrane, 2015: 39; Baser, 2017). Diasporas' nontransparent links with certain groups labelled "terrorist" in the home countries have drawn suspicion, and their engagement in homeland affairs has been suggested as increasing the risk of new armed conflicts or prolonging the already existing ones (Cochrane, 2015: 27). However, considering the action that diasporas engage in as perpetuators of homeland conflicts, Smith (2007: 11) argues that diasporic activities show no predetermined patterns in a situation of conflict.

On the other hand, diasporas' role as agents of peace that contribute to peace-building and post-conflict developments in their home countries has also been explored. Brinkerhoff (2011:120) maps the possible positive and negative effects that diasporas' engagement in conflict societies produce. Indeed, she argues that "the 'complex, contradictory and diffuse ways' diasporas impact on peace and security more broadly need to be accounted for in policies and programmes for peace, 
stability and post-conflict reconstruction and development." Smith (2007: 13) also states that "not all diasporas have the same capacities, opportunities or motivation to intervene in conflict and diasporas rarely are monolithic entities in terms of interests and objectives". Given the heterogeneity of diasporas and the multitude of factors that shape their engagement in both contexts, the role they play as mediators in peace-building or as conflict perpetuators, is far from clear-cut (Smith \& Stares, 2007).

Furthermore, not all diasporas nor their members engage in peace-building and/or conflict mechanisms. For once, there are always certain interests and motivations to engage or disengage, and even when engaged, diasporas need to have sufficient capacity and leverage to actually have an impact on policy-making mechanisms at home and abroad. These attributes are highly affected by a confluence of factors, not the least by the diaspora group's volume, political status, integration level, the existing national and international networks, and/or by corruption in the homeland. ${ }^{3}$ Furthermore, the political environment that diasporas operate in needs to have a system that is open to their influence. Lastly, conflicts and peace processes have their own dynamics that also shape diaspora activism, as exemplified in the Table 1 below.

Table 1. Diasporas in Peace and Conflict

\section{Phases of Peace and Conflict Diaspora Activism}

On-going Conflict Advocacy, lobbying, petitions, campaigning, sending financial support to armed groups, joining the army or the insurgent group as fighters and extra-territorial voting.

Peace Processes

Spoiling or supporting the process, getting involved as a third party, facilitating the host country's engagement in peace processes in the homeland, and taking part in the process as negotiators.

Post-Conflict Reconstruction
and Development

Making

investments, participating in return migration, development projects, development support, and providing assistance to foreign donors.

\section{Transitional Justice}

Lobbying for the recognition of genocide as well as taking part in truth commissions, healing, reconciliation and justiceseeking efforts.

Hence, diasporas' engagement in various forms of activities towards the homeland can all have both positive or negative impacts. These activities include among others:

- Direct economic remittances to homeland actors that can either have the impact of helping in post-conflict reconstruction and sustaining livelihoods during the conflict period (e.g. Somalia), and/or to create informal transfer systems that are used to support the continuation of conflict (e.g. Kosovo);

- Activities that have philanthropic aims, and that can support long-term knowledge transfer

\footnotetext{
${ }^{3}$ Several empirical case studies have shown the role diasporas play in peace-building and development (see Horst et al., 2010).
} 
(e.g. Afghanistan) and be used to achieve humanitarian goals (e.g. Haiti), and/or humanitarian aid that can be discriminatory (e.g. Somalia) and provide a cover for political objectives (e.g. Lebanon);

- Activities that aim to influence host country attitudes and policies via advocacy work and lobbying, and that can influence the international political opinion for the protection of human rights (e.g. Croatia) and/or can discourage actors to engage in peace negotiations (e.g. Irish diaspora).

Source: (Brinkerhoff, 2011: 120-123).

As we can see, the form, intensity and impact of diasporas' engagement in peace and conflict is dependent on both the host country and homeland political dynamics, being shaped by the stage of the on-going conflict or peace-building in the homeland context. Moreover, there can be considerable differences between diasporas groups' motivations and means to engage in homeland affairs. To understand better how diasporas organise and mobilise towards the homeland and what motivates their engagements, diasporas need to be considered as transnational non-state actors that operate on a deterritorialised basis.

This means that besides the homeland and host country context, diasporas also formulate action and motivations in what scholars have named the transnational space. The concept refers to a social space that extends across national borders, which entails cross-border activities, engagements, mobility, social relations and emotional attachments that diaspora groups sustain and forge within the host country, towards the homeland as well as towards the same diaspora's communities that have settled elsewhere (Bauböck \& Faist, 2010). The mobilisation that is, they are not confined within the borders of any particular nation-state. This is particularly evident concerning the virtual space through which diaspora members are informed of political and cultural matters relating to the homeland, which they employ to organise across national borders. Adamson and Demetriou (2007: 491) approach diasporas as having "the organizational and spatial logics of deterritorialized and network-based collective identities". In this sense, diasporas are non-state actors that operate in the transnational space, and whose networks, actions and motivations to participate are not limited within one particular nation-state.

The relationship between diaspora groups and the homeland, whether real or imagined, is one of the components in the formation of diasporic identity. The relationship with a homeland is not automatically ruptured at the departure, nor does it continue in the same format as in the homeland. This is particularly true for ethno-national diaspora groups, the activism of which towards homeland can be highly politicised and rooted in nationalist aspirations and identity politics (Sheffer, 2003). The sustaining of diasporas' engagements, whether they are political, economic, cultural, linguistic or other, can also be, to some extent, founded on a collective sense of identity and belonging, but it would be reductionist to approach homeland engagement merely as an expression of (national) belonging. The sense of diasporic identity does not automatically translate into participation in homeland affairs, although it can motivate such engagements. Similarly, engagements with the homeland do not necessarily evoke a sense of belonging, but can rely on extant transnational networks and stem from more general philanthropic motivations to provide assistance to conflict areas. 


\section{Diasporas' Multiple Roles in Peace and Conflict: The Triadic Relationship}

Besides the transnational space in which diasporas operate, diaspora activism is also conditioned by national contexts and the interactions between both state and non-state actors. It has been suggested that there is a triadic relationship among diasporas, the states and the contexts where such groups reside, and the homeland states as well as the settings where they or their forbears come from. Diaspora theories have been structured around the multi-faceted relationships between these three actors (Vertovec, 1999; Demmers, 2002). Each dimension has an impact on diaspora's outreach and behaviour towards peace and conflict in terms of determining the scope of their actions.

Levitt and Glick Schiller (2004: 1023-1024) argue that states can be categorised based on the way they treat long-distance members, these being: transnational nation-states, strategically selective states as well as disinterested or denouncing states. The dynamics of the interaction between the two, therefore, does not automatically bring about unconditional solidarity. As Cohen (1996) points out, diasporas' relationship towards the homeland government have transformed from being "victims" to being "challengers". Hence, the relationship between the two is more often asymmetrical, meaning that one is more dominant than the other, depending on the political, economic and social situations in the home country, and they can shift over time. Nevertheless, the strength of relations between the homeland and the diaspora is one of the main determinants of diasporic mobilisation.

Home countries exercise active diaspora policies to tap better into these communities' economic, social and political resources as well as human capital (Pirkkalainen and Abdile, 2009; Horst et al., 2010). Regarding which, homeland politicians have mobilised to create diaspora ministries and to formulate policies towards their overseas members. Several examples of this exist, including Chinese, Mexican, Russian, Indian, Hungarian, Filipino and Haitian diaspora groups (Varadarajan, 2010). These have been aimed at attracting remittances and foreign investment by pursuing a highly determined policy to strengthen diaspora-homeland ties (Østergaard-Nielsen, 2003:211). There has also been a growing trend of granting diasporas extra-territorial voting rights, where they are considered potential voters targeted by transnational election campaigns (see Varadajaran, 2010: 15).

Furthermore, homeland governments have interests in creating relations with their diaspora abroad, as it gives them power of leverage in the policy-making procedures of the host country. Diaspora groups might be expected to lobby host country governments for homeland interests or the latter could assume that diaspora groups can build bridges between the two. Moreover, given the diaspora can consist of groups with differing ideological, ethnic or religious attachments, home states tailor multiple diaspora engagement policies to interact with their citizens abroad. Separate from the state-linked groups, certain elites in the home country can engage in mobilising different sub-groups in the diaspora community to expand their interests and ideologies abroad. In such cases, usually government-friendly diaspora groups are chosen to become a tool of soft power and public diplomacy by the governing elite, as in the case of the Turkish diaspora (Aydin, 2014). This is also one of the reasons why minority nationalisms find an enabling environment abroad for flourishing (Eccarius-Kelly, 2008).

Whilst diasporas can be perceived as an asset, they can also be considered a liability by some home states, in that the transnational space provides a space for contestation, for instance, against authoritarian governments. Home states can then aim to curb undesirable diaspora activism, while 


\section{Diasporas' Multiple Roles in Peace and Conflict: A Review of Current Debates}

simultaneously promoting the groups that share their political agenda. Indeed, local power struggles can also become deterritorialised and have an impact on how different diasporas groups are positioned vis-à-vis the home state. Hence, diaspora activism can take two forms in the eyes of the home state: conflictual and complementary. Conflictual modes of action can include advocacy work, protests, lobbying host country governments, forming governments in exile, establishing solidarity with other diaspora and civil society organisations in the host country and putting pressure on the home state for policy change on certain issues. Complementary actions can be examined within the soft power and public diplomacy framework, with diaspora (or sections of it) following the home state agenda to strengthen national interest driven images and ideas abroad. These issues clearly cause friction, not only between diasporas and homelands, but also between home and host countries as well as between rival diaspora groups.

The relationship between the hostland and diaspora is also crucial for diaspora mobilisation and engagements towards homeland. As Shain and Barth put it: "The basic nature of the hostland regime determines the ability of a diaspora to organise influence; indeed, it determines the ability to organise at all" (2003: 463). The opportunity structures in the hostland, namely the institutional and political ones, are one of the most significant determinants of the level of mobilisation in the diaspora (Sökefeld, 2006). How much space the host country gives to the diaspora to express its own agenda and to what extent such people can organise their own civil society groups, associations or the like, determines the success of diaspora involvement, both in homeland and host country political affairs. Moreover, the extent to which the host state allows the community to exert an influence affects also the worth of the diaspora as a foreign policy asset or liability in the eyes of the homeland (Shain \& Barth 2003: 463).

In general, host country approaches towards diaspora activism on its soil can take three forms: enabling, passive and hindering. Diaspora are more likely to succeed in having an impact in homeland affairs, if the host country offers an enabling environment for it to mobilise locally and transnationally. For instance, the Kurdish diaspora in Sweden has been able to create greater visibility for the poor human rights situation of Kurds in the Middle East, via active advocacy work and lobbying of the local policy-makers. However, host countries may also implement policies that might hinder diaspora activism, as is the case with Liberation Tigers of Tamil Eelam (LLTE), which has been able to mobilise diaspora members to the extent of having a direct impact on the conflict in Sri Lanka. Listed as a "terrorist organization" by the United Nations in 2001, similar to the PKK (Kurdistan's Workers' Party), which was listed as a "terrorist organization" by the European Union in 2002, diaspora activism related to these organisations has been to varying degrees criminalised and hindered in host countries (Potters, 2010). In certain cases, the host country might remain apathetic to diaspora movements, if they do not raise politically sensitive issues or possess enough power for leverage.

Moreover, the attitudes of host countries to diaspora activism are prone to change over time and are, in no small part, affected by the diplomatic and other relations between the home and the host country. The relations between the homeland and the host country can come under stress if the authorities in the former wish to curb or accelerate diaspora formation of a certain group in the latter. In order to play a role in peace-building and conflict transformation in the homeland, both home and host states would need to accept diasporas as potential actors that have agency. Otherwise, their contributions risk having no real impact on the actual processes of democratisation and peacebuilding back home, provided it is in the interests of different actors. 
As this brief overview of the research literature on diasporas' multiple roles to peace and conflict shows, their participation in homeland peace-building and conflict perpetuation is highly context-dependent. It varies between different diaspora groups and depends on the triadic relationship between the diaspora, host country and homeland. In addition to this, we wish to highlight two other understudied aspects that affect how peace and conflict dynamics play out as well as how they potentially change over time. The first is the diaspora-diaspora relations that we argue as being essential to how they mobilise and formulate their homeland engagements. The second, is the generational dynamics, in other words, how peace and conflict dynamics can not only be transmitted to subsequent generations, but also change shape in the process. These two aspects will be discussed next in more detail.

\section{Diaspora-Diaspora Relations: Moving Beyond the Triadic Relationship}

While this triadic relationship has received considerable attention from scholars, intra-group interactions between diaspora groups are highly understudied. Many scholars and other experts have ignored the fact that several different diaspora groups can originate from the same country and can reproduce the homeland conflict dynamics in the host country. These conflicts can be referred to as "cold conflicts' (McMahon \& Chow-White, 2011), which do not grab the attention of media outlets and experts as they are not "hot" enough to be noticed. However, transnational spaces can also become platforms for the reproduction of hegemony struggles among various actors or for the transmission of structural and cultural violence mechanisms, as defined by Galtung (1996). Migration experience will not wash away the legacies of existing or past conflicts; the political cleavages and intra-group violence that the homeland conflict has produced can linger and be transmitted to the host country context. That is, homeland conflicts inherently spill-over to the transnational space. However, they are not an exact reflection of the conflict that one can observe in the home country. Hence, while we should acknowledge the path-dependency that diasporas have towards the homeland's political frames, tensions between rival groups may also be regenerated in different forms in the host country and conflict dynamics take on a different shape according to the new environment. Conflicts between two groups may reappear not only because of a community's strong retention of the past, for the conflict dynamics may come into being owing to the unequal power relations or ethnic hierarchies that are reproduced in the host country context. These imbalanced power relations are recreated in different shapes and forms in the host country by a combination of several factors. New opportunities in the host country include shifts in the symmetries of power relations between the two conflicting groups that might pave the way for dramatic changes in inter-group conflict dynamics that result in a transformation in the density, depth and content of the conflicts (see Baser, 2015; Pupcenoks, 2015; Féron, 2017).

The tensions that are rooted in homeland conflicts might reveal themselves in the host country in the form of clashes between rival groups, especially at critical junctures in the homeland situation. Whilst usually the violent interactions receive more visibility, counter-hegemonic struggles and mechanisms of contesting sovereignty may stay subtle but they do not disappear. Violent outbreaks not only make contentions become apparent, for they also pave the way for stigmatisation of these groups and add to the debates related to migration and integration in host states. Either way, this subject requires more scrutiny. If the conflict stays dormant without any violent outbreaks, then it stays in the form of a "cold conflict' (McMahon \& Chow-White, 2011). This may then lead to a "negative peace" or as Galtung (1996) puts it, to a situation where there is no direct political violence, but there is mistrust between the members of certain communities. 


\section{Diasporas' Multiple Roles in Peace and Conflict: A Review of Current Debates}

There are various examples of ethnic groups - such as the Tamils and Sinhalese in Canada, Turkish Cypriots and Greek Cypriots in London, Serbs and Croats in Australia - who have tried or are still trying to settle their issues in their host countries via protests or civil society organisations, in parliaments, or even in the back streets of migrant-populated districts. Such conflict import has been discussed by authors, such as Skrbis (1999), who discovered that the host country context greatly affects diaspora groups' repertoires of actions. Danforth (1997) has focused on GreekMacedonian relations and inter-group rivalries in Australia, by examining the transnational dimension of "global cultural wars". Given most studies have focused on examining how diasporas channel their energy to influence homeland and host country policies, the dynamics of conflict and peace that can create cleavages or forms of cooperation between different diaspora communities have remained largely understudied. Similarly, diasporas' role in homeland peace-building or in the reproduction of homeland conflicts, as they take place in virtual spaces and via the new media, deserves more attention than it currently receives.

\section{What about the Second Generation?}

Diasporas are heterogeneous in terms of their members' social class, education, language, religion, political affiliations, cultural habits, and even at times ethnic background. The generational aspect adds to this diversity. The focus regarding peace and conflict studies has long been on the first generation and understandably so. However, the first-generation's experiences, cross-border contacts and attachments towards homeland differ from those of their children, most often born and raised in the host country. The experience of departure, migration or even exile is a lived experience for the first generation, whereas for the second it is evoked, remembered and enunciated in the transnational space they are embedded in. The relationship to (ancestral) homeland is evidently different, but not necessarily meaningless, when it comes to questions of peace and conflict in their parents' homeland.

Some scholars have argued that the phenomenon of transnational activities and ties towards the homeland mainly concern the members of the first generation (Portes \& Rumbaut, 2001), for their children express fading interest towards their ancestral homeland. However, there is also evidence that second-generation members continue to engage transnationally (Levitt, 2009; Toivanen, 2014). Furthermore, second generation members, who have been more passive and "dormant transnationalists" (see Shain \& Barth, 2003), can become activated in the aftermath of major political disturbances in their parents' homeland. One such example was witnessed during the Gezi park protests that took place at the Taksim Square, Istanbul in May-June 2013. It soon resonated among the diaspora communities settled in Europe, sparking demonstrations that included second-generation members in Sweden, the Netherlands, France and Germany (Baser 2015). A similar phenomenon was observed in the context of the Arab Spring, where first and secondgeneration mobilised in the Arab diasporas and made demands to homeland and host governments (Beaugrand \& Geisser, 2016).

The second generation's diaspora activism can include: participating in political demonstrations advocating for a homeland-related political cause in the host country, sending economic remittances via humanitarian aid, taking part in skills and knowledge transfer via diaspora knowledge networks or engaging in actual combat in their parents' homeland. One example of such long-distance participation can be found among the Kurdish diaspora movement, when secondgeneration members mobilised in the aftermath of the siege of the Kurdish city, Kobane, in 2014 (Toivanen, 2020 forthcoming). The second generation is arguably more familiar with their parents' 
host country, speak the majority language as their mother tongue, and also have different means and possibilities for participating in transnational activities geared towards their ancestral homeland. They are much more integrated - economically, socially and politically - compared to their parents, which, concerning lobbying for instance, makes them have different access mechanisms to the policy-making circles in both contexts.

Studies have shown that the homeland conflict dynamics are not only transported by the firstgeneration members to host countries, but also, to some extent, perpetuated in the second generation (Baser, 2015). Similar to studies on the first generation, the context is also significant in the case of second-generation mobilisation. Comparing second-generation Kurds and Turks in Germany and Sweden, Baser (2015) shows how host country policies, attitudes and institutions play a role in the conflict perpetuation from the first to the second generation. The second generation's views on homeland conflicts, means as well as motivations to engage in peace-building or conflict perpetuation can also be dramatically different from those of their parents, and not necessarily based in diaspora networks. For instance, Hess and Korf (2014) show how second-generation Tamils in Switzerland mobilised politically during the final battle of the civil war in 2009 in Sri Lanka. The authors discovered that two factors played into their mobilisation. The first was the multiple senses of belonging they fostered both towards Sri Lanka and Switzerland, whilst the second was the simultaneous witnessing of the suffering of Tamils combined with the perceived lack of interest by Switzerland. They concluded that this gave way to a new form of diaspora activism that was located in and bound to the host country.

The second generation can also have a different take on homeland conflict and the existing political divisions than their parents. The intra and inter-ethnic disputes can give way to political unity that transcends ethnic or political divisions between and within the diasporas. Toivanen's study (2020 forthcoming) shows how Kurdish second-generation members referred to the geography-based political divisions existing within the Kurdish diaspora community in France and Finland that had led the first-generation Kurds to mobilise through different political groups. However, the second-generation members felt these "old-world" divisions to be of less importance, and emphasised a common identity as "Kurdish", instead of "Iraqi" or "Turkish" Kurdish, for instance. Moreover, the second generation constructs its identity and belonging in relation to both the ancestral homeland and country of birth, which is also reflected in intra- and intergroup relations. Therefore, we argue that it is essential to include a focus on the generational dynamics when examining a diaspora's multiple roles in peace and conflict. For, this opens avenues to examine how diasporas' role in peace-building and conflict perpetuation does not remain static, but rather, can transform over time and over subsequent generations.

\section{Conclusion}

In this article, we have shown how diasporas' activities can varyingly contribute towards peace-building processes or perpetuate conflict back home. Hence, their role in homeland affairs cannot be approached as either "peace-makers" or "peace-breakers", since diaspora activism, be it economic, political or cultural, can support peace-building processes and also feed into intra-ethnic conflicts and disputes back home in a variety of ways. What modern-day diasporas share as a common attribute, however, is the fact that they have become significant transnational non-state actors that operate on a deterritorialised basis (Bauböck \& Faist, 2010). Herein lies also their power and potential for organisation and mobilisation. 


\section{Diasporas' Multiple Roles in Peace and Conflict: A Review of Current Debates}

Simultaneously, diaspora activism is shaped by the existing relations between the triad of the homeland, host country and diaspora. In addition to paying attention to this triadic relationship, we further argue that two understudied aspects deserve more scholarly attention. That is, in order to gain a better understanding of diasporas' role in homeland peace and conflict, there is a need to pay attention to diaspora-diaspora relations and the generational dynamics. This means taking into consideration how inter and intra-ethnic conflicts are reproduced and transmitted in diaspora, that is, being, at times, passed down to subsequent generations, whose members can then have a different take on such conflicts. Moreover, diaspora-diaspora relations can also be significant in building peace, where intra-ethnic disputes can give way to political unity that, over time and with subsequent generations, transcends ethnic and political divisions.

\section{References}

Adamson, F. B., \& Demetriou, M. (2007). "Remapping the boundaries of 'state' and 'national identity': Incorporating diasporas into IR theorizing". European Journal of International Relations, 13 (4): 489-526. https://doi.org/10.1177/1354066107083145

Aydın, Y. (2014). The new Turkish diaspora policy: its aims, their limits and the challenges for associations of people of Turkish origin and decision-makers in Germany. SWP Research Paper.

Baser, B. (2015). Diasporas and Homeland Conflicts: A Comparative Perspective, Farnham: Ashgate. https://doi.org/10.4324/9781315577012

Baser, B. (2017). "Intricacies of engaging diasporas in conflict resolution and transitional justice: The Kurdish diaspora and the peace process in Turkey". Civil Wars, 19 (4): 470-494. https://doi.org/10.1080/13698249.2017.1396528

Bauböck, R., \& Faist, T. (eds.). (2010). Diaspora and transnationalism: Concepts, theories and methods. Amsterdam: Amsterdam University Press. https://doi.org/10.5117/9789089642387

Beaugrand, C., \& Geisser, V. (2016). "Social mobilization and political participation in the diaspora during the "Arab Spring". Journal of Immigrant \& Refugee Studies, 14 (3): 239-243. https://doi.org/10.1080/15562948.2016.1212133

Brinkerhoff, J. M. (2011). "Diasporas and conflict societies: conflict entrepreneurs, competing interests or contributors to stability and development?". Conflict, Security \& Development, $11 \quad$ (02): 115-143. https://doi.org/10.1080/14678802.2011.572453

Cochrane, F. (2015). Migration and Security in the Global Age: Diaspora Communities and Conflict. Oxon: Routledge. https://doi.org/10.4324/9781315881768

Cohen, R. (1996). "Diasporas and the nation-state: from victims to challengers". International Affairs (Royal Institute of International Affairs 1944-), 72: 507-520. https://doi.org/10.2307/2625554

Danforth, L. M. (1997). The Macedonian Conflict: Ethnic Nationalism in a Transnational World. New Jersey: Princeton University Press.

Demmers, J. (2002). "Diaspora and conflict: Locality, long-distance nationalism, and delocalisation of conflict dynamics". Javnost-The Public, 9 (1): 85-96. https://doi.org/10.1080/13183222.2002.11008795

Eccarius-Kelly, V. (2008) "The Kurdish conundrum in Europe: Political opportunities and transnational activism". In: Pojmann, W. (ed.) Migration and Activism in Europe since 1945. New York: Palgrave Macmillan. https://doi.org/10.1057/9780230615540_4

Faist, T. (2002). "'Extension du domaine de la lutte': International migration and security before and after September 11, 2001". International Migration Review, 36 (1): 7-14. https://doi.org/10.1111/j.1747-7379.2002.tb00065.x

Féron, É. (2017). "Transporting and re-inventing conflicts: Conflict-generated diasporas and conflict autonomisation". Cooperation and Conflict, 52 (3): 360-376. https://doi.org/10.1177/0010836716671759

Galtung, J. (1996). Peace by Peaceful Means: Peace and Conflict, Development and Civilization. London: Sage.

Horst C., Ezzati R., Guglielmo M., Mezzetti P., Pirkkalainen P., Saggiomo V., Sinatti G. \& Warnecke A. (eds). (2010). Participation of Diasporas in Peace-Building and Development. A Handbook for Practitioners and Policymakers. Peace Research Institute: Oslo.

Levitt, P. (2009). "Roots and routes: Understanding the lives of the second-generation transnationally". Journal of Ethnic and Migration Studies, 35 (7): 1225-1242. https://doi.org/10.1080/13691830903006309

Levitt, P., \& Schiller, N. G. (2004). "Conceptualizing simultaneity: A transnational social field perspective on society". International migration review, 38 (3): 1002-1039. https://doi.org/10.1111/j.1747-7379.2004.tb00227.x

McMahon, R., \& Chow-White, P. A. (2011). "News media encoding of racial reconciliation: Developing a peace journalism model for the analysis of 'cold' conflict". Media, Culture \& Society, 33 (7): 989-1007. https://doi.org/10.1177/0163443711415742 
Østergaard-Nielsen, E. (2003). Transnational Politics: The Case of Turks and Kurds in Germany. London: Routledge. https://doi.org/10.4324/9780203361627

Pirkkalainen, P. \& Abdile M. (2009). "The diaspora - conflict - peace - nexus: a literature review", Diaspeace working paper nro 1, University of Jyväskylä, Jyväskylä.

Portes, A. \& Rumbaut, R. G. (2001). Ethnicities: Children of immigrants in America. California: University of California Press. https://doi.org/10.1525/california/9780520230118.001.0001

Potters, M. (2010). "Engaging the Tamil diaspora in peace-building efforts in Sri Lanka." Undergraduate Transitional Justice Review, 1 (3): 260-274.

Pupcenoks, J. (2015). Western Muslims and Conflicts Abroad: Conflict Spillovers to Diasporas. London: Routledge. https://doi.org/10.4324/9781315690179

Safer World. (2016). "Peace and Migration: Realising the Links". Published in September 19th, 2016. Retrieved from: https://www.saferworld.org.uk/resources/news-and-analysis/post/206-peace-and-migration-realising-the-links

Shain, Y., \& Barth, A. (2003). "Diasporas and international relations theory". International organization, 57 (3): 449-479. https://doi.org/10.1017/S0020818303573015

Sheffer, G. (2003). Diaspora politics: At home abroad. Cambridge: Cambridge University Press. https://doi.org/10.1017/CBO9780511499432

Skrbis, Z. (1999). Long-distance Nationalism: Diasporas, Homelands and Identities. Brookfield USA: Ashgate.

Smith, H. (2007). "Diasporas in international conflict". In H. Smith and P. Stares (eds.) Diasporas in Conflict: Peacemakers or Peace-Wreckers? Tokyo: United Nations University Press.

Smith, H. A., \& Stares, P. (2007). Diasporas in Conflict: Peace-makers or Peace-wreckers?. Tokyo: United Nations University Press.

Sökefeld, M. (2006). "Mobilizing in transnational space: a social movement approach to the formation of diaspora". Global networks, 6 (3): 265-284. https://doi.org/10.1111/j.1471-0374.2006.00144.x

Toivanen, M. (2014). Negotiating Home and Belonging - Young Kurds in Finland, PhD Thesis, Turku: University of Turku.

Toivanen, M. (2020 forthcoming) A Comparative Study of Kurdish Diaspora Mobilisation: The Kobane Generation?, Helsinki: Helsinki University Press.

United Nations. (2019). "The number of international migrants reaches 272 million, continuing an upward trend in all world regions, says UN", 17 September, https://www.un.org/development/desa/en/news/population/internationalmigrant-stock-2019.html.

Varadarajan, L. (2010). The Domestic Abroad: Diasporas in International Relations. New York: Oxford University Press. https://doi.org/10.1093/acprof:oso/9780199733910.001.0001

Vertovec, S. (1999). "Conceiving and researching transnationalism". Ethnic and racial studies, 22 (2): 447-462. https://doi.org/10.1080/014198799329558. 
58 Diasporas' Multiple Roles in Peace and Conflict: A Review of Current Debates 